Meta

Journal des traducteurs

Translators' Journal

\title{
My Life as Translator
}

\section{Gabrielle Mauriello}

Volume 38, numéro 4, décembre 1993

Le $J e$ du traducteur

The $I$ of the Translator

URI : https://id.erudit.org/iderudit/003605ar

DOI : https://doi.org/10.7202/003605ar

Aller au sommaire du numéro

Éditeur(s)

Les Presses de l'Université de Montréal

ISSN

0026-0452 (imprimé)

Découvrir la revue

Citer cette note

Mauriello, G. (1993). My Life as Translator. Meta, 38(4), 731-734.

https://doi.org/10.7202/003605ar

\section{Résumé de l'article}

L'auteur analyse sa vie professionnelle de traductrice. Elle décrit ses efforts, ses joies et ses déceptions. 
I would like to call these few considerations and thoughts "going around in a complete circle" or "looping the loop." In fact, looking back (without anger, I hope) at my life as translator, I can see now that I'm approaching again the point from where I started. Obviously, on a different level.

I will begin from where it all started. It is not a very exciting or unusual story, so I cannot really see what kind of interest it may raise in the readership of this magazine. However, I hope there will be fellowtranslators who do recognise flashes of their life and who feel they can share some of my sorrows, complaints, joys, hopes and, above all, purposes. In other words - translators of the world, unite!

I don't know if any of you remember big dreams of his / her childhood. My big dream was to learn all languages of the world, or as many as possible. It was simply unacceptable to me that people should be doomed not to understand each other because of a language barrier (I was too young to know all about Babel).

So I decided very early in my life (I was perhaps 5 years old) that this was not going to be my case - I was going to learn all existing languages, to meet people from all different countries of the world and understand their way of life, their way of thinking, their religions and so on.

In my reveries, the best way I could think of to put the whole project into practice was to become stewardess: I would travel over the whole world and learn all the things I was eager to know. In my imagination, to be a stewardess meant a life full of mystery and exciting discoveries. I used to spend long hours looking at bookstalls of the very poor market of my village and the nearby little town and spent all my pocket money (not much) in grammars and textbooks.

In the village where I lived we only had a rather shabby library where I hardly ever found what I was looking for, except books on religions. Foreign tourists were my favourite victims, and as soon as I got to secondary school I started corresponding with foreign pen-friends in (horrible, I suppose) French and German, which I had learnt in the do-it-yourself craftsman-like fashion I have just described.

The big dream, and the idealistic project behind it, was to be able to help people understand each other and so, to the extent of my very limited possibilities, to contribute to creating a peaceful world.

Later on, towards the end of my secondary school curriculum, I suddenly realised that the best way to put my dreams into practice was not to be a stewardess but an interpreter. At that time (end of 50s) interpreters were hardly known; it was a new profession, full of promises and expectations. OK, I said to myself: that's your line.

However, there was a problem: in Italy, there were just two university-level schools for interpreters and translators (a four-year course), one in Rome and one in Milan, both belonging to the same private organization and both very expensive.

Résumé

L'auteur analyse sa vie professionnelle de traductrice. Elle décrit ses efforts, ses joies et ses déceptions.

\section{MY LIFE AS TRANSLATOR}


My family did not quite agree with my decision - after all, it meant leaving the village and going to the big city and, even more upsetting to them, living on my own; something on the fringe of scandal for conservative villagers of post War Tuscany, especially if it was a girl, and not a boy, to break with tradition. Additionally, my family was not able to support me financially anyway; so I had to think of a way of earning my leaving and paying for the school.

To overcome all these problems I took a decision that was going to prove very fortunate for my professional training. I went abroad: first to Germany and then to England, to learn the respective languages on site, instead of going to school. Of course, I worked to support myself and also went to evening school. And, above all, I saved a lot of money, since on my return to Italy I was permitted to skip the first two (introductory) years at the Institute for Interpreters and Translators of Milan and only paid the rates for the third and fourth years of the curriculum.

Apart from this very prosaic detail, learning the language abroad was much easier and, especially in London, I had a fabulous time (we were in the swinging Sixties, and I certainly was an "absolute beginner").

Now, you may argue that going to parties is not a very traditional way of learning a language, but I can assure you that it is very educative. At that time, and probably still in these days, you could walk down the road in certain districts (especially Kensington) and find signs on the doors saying "a party is on," and you would join the lot and have fun. After midnight, when most people were beginning to be tired of dancing, we would sit down on the floor and discuss serious and less serious matters. This was really what I enjoyed the most: a very cosmopolitan gathering, talking of the things of life and of customs in the various countries. Knowing the language really made sense: it took you to numberless worlds, it put you in touch with a variety of civilizations and gave you the opportunity to exchange views with people of so many different cultures and to understand their way of life.

When I came back to Italy, I went to Milan where I had decided to sit the exams of the Institute for Interpreters and Translators to be admitted to the third year of their courses.

I passed the exams and started a new life of work and study - working during the day as an executive secretary, to support myself, and going to school at night. It was certainly hard, but a wonderful period.

With some fellow-students of the school, who had been to London and loved the idea of clubs, we even tried to create what in our intention was to be a sort of linguists' club - a meeting point for people who loved languages. The idea behind it was to encourage people to meet and to get to know other people. The venture was very successful, but times were not ripe for linguists' clubs and we became, without realising it, a cabaret d' essai. That's life.

After this short parenthesis, and after graduating, I started working as an interpreter and translator. I really was like a bee, flying from flower to flower, never stopping for too long, never satisfied with what I was doing; one day working in fairs and exhibitions as interpreter, the next day as a temporary replacement with a company; one day doing written translations, the next day travelling with a delegation abroad.

I was trying to understand my way and there was not much I was sure of, at that time, except that I still wanted to meet people from other countries, other cultures. It did not matter much wether I did this by travelling on holliday, or working with people, or reading books and studying. I went to school again to study Russian, Japanese and Chinese. God knows what I was looking for...

I even had my Indian period, like the Beatles. Together with my boy-friend, we bought a secondhand Volkswagen van, left everything behind and travelled to the East, following the Silk Route, on Marco Polo's trail. We lived here and there for months - Turkey, Iran, Afghanistan, India, Nepal... Like many young and less young people that we met "on the road," we would buy and sell things, barter "Western" consumer goods such as record-players, blue-jeans, hair-dryer, radio set and cassettes, for silk fabric, jewels, sitars...

There again, knowing languages was important, because it made it easier to get in touch with local people and with fellow wanderers, exchanging views and sharing experiences.

Back from India, a little older and wiser, I began so-to-speak to settle down. I wanted to stop wandering. Living from hand to mouth, without knowing where I would go next, was no longer so appealing to me. I thought that it might be a good idea to do some translations during the winter and then work in tourists villages during the summer (I love the sea), as I had been doing for some years before travelling to India.

But the days of unrest were approaching the end. I felt that what I really wanted to do was to work on my own as a translator, leading a more ordely life and setting my thoughts to rights. Also, for the first time, I found that working as an (ad hoc) interpreter, as I occasionally still did, was frustrating, because I never got the chance to get deeper into a subject, to become an expert - it was like a dress fitting too thight. I felt I wanted to think and select one or more areas that were appealing to me, in which to specialize.

And, as usual in life, when you are ready for it, love comes. In my case, it was love at first sight. I had the opportunity, quite by chance, to work in a renowned international Law Firm, replacing their translator, and I fell in love with legal translations.

This happened a long time ago ( 20 years) but I am still faithful. When I look back, I feel that work during these twenty years has sometimes been hard, but always very rewarding. Really, I can consider that I was born 20 years ago as a translator, since the ten years before that have been a long search - collecting experiences, completing the picture to be able, in the end, to find my way. 
During such twenty-year period, I have been working and studying and learning with enthusiasm, growing in experience and self-confidence, discovering the wonderful, difficult job of creating a translated text.

Every translator who loves his/her job knows the deep joys and sorrows of creating. There comes a time when you think you can at last be happy with your work; and shortly after you feel that it does not work at all, that somehow you have lost control over the text, you are no longer able to mould it as you would want it. If you are old enough, you will know that this feeling is cyclical. It comes just before an improvement, a sort of leap forward in the quality of your work. But happiness will not be too long, it will soon be followed by a creaping period of dissatisfaction and crisis.

It is of comfort to me to think that if I were permanently satisfied with my work I would probably be a bad translator.

Anyway, I set up my own little office and went more or less happily along, between lights and shadows.

I realised pretty soon that the market was very loose and undefined, practically without barriers to entry. I was amazed all the time at the numberless types of persons who purported to be translators. Most of them did not have a training, but this was not the worst thing, because you can be an excellent translator even without a specific training. The poin was that, in the absence of a definition of some kind of professional profile, every student, every housewife, every teacher of languages, every foreigner who happened to live in Italy assumed to be able to translate. Not to mention translation agencies: there were lots of them, managed by non-translators, whose only purpose was to make money and exploit the situation (largely so even today).

With very few exceptions, there was a large population of would-be translators, who knew nothing of professional behaviour, code of ethics and the like. On the other side of the road, there were clients who thought that a translator was "somebody who knows foreign languages," or, at best, a slot-machine with text being fed in at one end and coming out translated at the other end, obviously at high speed. This has not changed much, I am afraid.

Now, I loved my profession very much and I wanted it to be respected and appreciated. After all, translators had a very important role to play in society: they were the best bridges between cultures. That's what I thought then, and I still think. So 1 felt that I had to do something about such unfair state of things, I had to make my contribution towards improving the status of translators in the market where I was working and in the society where I lived.

This was roughly ten years ago, when my "adventure" as an active member of AITI (Associazione Italiana Traduttori e Interpreti), began. I was firmly convinced that we had to get together to be stronger and to obtain better conditions of work and more social recognition. The Association of Trans- lators and Interpreters was one of the ways. The other way was joining forces with a number of select colleagues, sharing resources and building on our strengths to fight agencies and the grey market.

There have been highs and lows during these ten years: lots of disappointments, battles lost, unsuccessful ventures. But also deep joys and gratifying acknowledgments. I view it as success, for instance, to have been able to create a partnership with one of my early students, which is now a well established venture. Also, I am very happy about the fact that we have a joint-venture with four additional colleagues who share with us office space and other resources.

A big challenge was my involvement in the teaching profession. I had always thought, in my early days, that teaching was not my line; and if someone had told me that I was going to enjoy it, I would certainly have considered him crazy. But so it went. I was asked to teach translation (general and technical) at the School for Translators and Interpreters of the Municipality of Milan (a university-level school) about ten years ago (that must have been a time of radical change in my astral picture!). And I must say, it has been a wonderful experience. In a way, I am convinced it was all written in the stars. When I accepted the appointment I thought: "why not." It was going to be an experiment, just to try. After all, I wanted to be able to contribute to changing the situation of the market, and training translators could be one of the ways of doing it.

My commitment in the Association and in the School has gradually increased over the years, with very positive and mutually fertilizing intersections between these two areas and my professional activity. It now looks to me very much like a loop: when I translate, I very frequently stop and think about the process, with the School in mind. I take notes of interesting problems and solutions that may turn useful in the classroom. In turn, when I am teaching, I have to get deeper into certain transiation problems, I have to think of theory and explanations; and this helps me, in the end, improve my translation skills.

Training translators also means paving the way for a stronger generation of professionals, in the hope that one day they will join the Association and make it more powerful. From practice to theory, to teaching, to affecting the market and finally getting the regognition and status that translators deserve. There the loop would happily close.

If I had to weigh the achievements of my life in the balance, I would say that $I$ am satisfied with my professional choices. I have enjoyed the good times and have learned from bad periods. My love for this profession is still passionate and enthusiastic as it was at the beginning. Luckily, because there is a long way to go, here in Italy, before we obtain what we are fighting for.

I have big plans for the future. A lot can be done for our profession if we all work in close cooperation and link up with each other across frontiers. 
We often hear that this would be a better world if it were governed by women. Think, for a moment, of a world governed by translators... After all, they know the secret pleats of different cultures better than anybody else.

\section{GABRIELla MAURIELLO}

Milano, Italy 